\title{
A Method for Extraction of Function Modules of Sequential Control Programs Based on Structure Analysis
}

\author{
Satoshi Nakamura Non-member (Yokohama National University) \\ Yasutaka Fujimoto Member (Yokohama National University, fujimoto@ynu.ac.jp)
}

Keywords: sequential control, function module, hierarchical structure, Markov chain, reachability matrix

PLC based controls are widely used in industry field. In general, the Ladder Diagram (LD) is a most common programming language for such discrete control systems. Although LD is very simple and easy to learn, it is difficult to develop and maintain complicated systems due to its simplicity. A solution for this problem is to develop and reuse function modules and to treat them as a black box.

In this paper, a method to extract function modules from sequential control programs for a reuse purpose is proposed. It is effective for a cost reduction of development of control systems. A hierarchical structure of a given logic control program can be found by using association graph that represents a relation of variables appeared in the logic control program. If some or more variables are connected each other (strongly connected), the layered structure is not easy to find. Thus, based on the concept of Markov chain, the importance of variables can be conducted. We propose a new method to divide unclear-layered variables in more details. An illustrative example of a tank control program is shown as an application of the proposed method.

Figure 1 shows an example of a given ladder diagram for a tank system as shown in Fig. 2. Using an association matrix derived from a relation of the variables, the proposed mathematical procedure produces a rank of variables and a layered structure as shown Table 1 and Fig. 3. Using the layered structure, each set of the variables and corresponding steps in the LD program can be extracted as a function block.

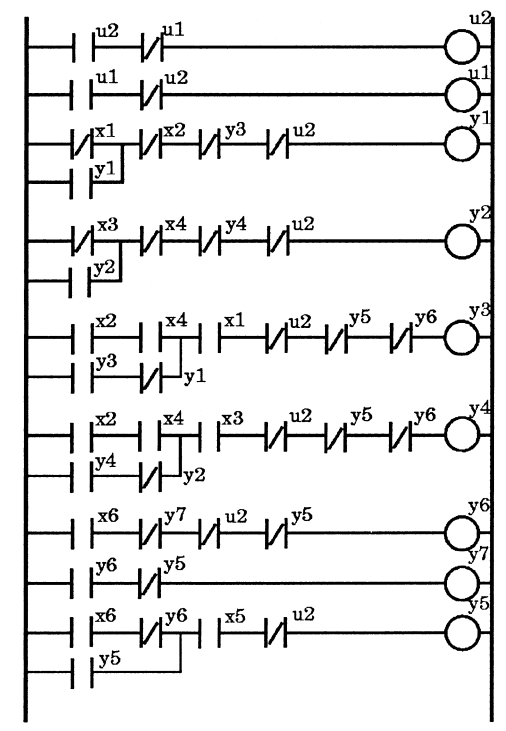

Fig. 1. A ladder diagram for a tank system
Table 1. A rank of variables

\begin{tabular}{|l|l|}
\hline $\mathrm{y} 1$ & 0.193 \\
\hline $\mathrm{y} 2$ & 0.193 \\
\hline $\mathrm{y} 3$ & 0.208 \\
\hline $\mathrm{y} 4$ & 0.208 \\
\hline $\mathrm{y} 5$ & 0.0312 \\
\hline $\mathrm{y} 6$ & 0.0245 \\
\hline $\mathrm{y} 7$ & 0.0111 \\
\hline $\mathrm{u} 1$ & 0.0286 \\
\hline $\mathrm{u} 2$ & 0.0286 \\
\hline $\mathrm{x} 1 \sim \mathrm{x} 6$ & 0.0125 \\
\hline
\end{tabular}

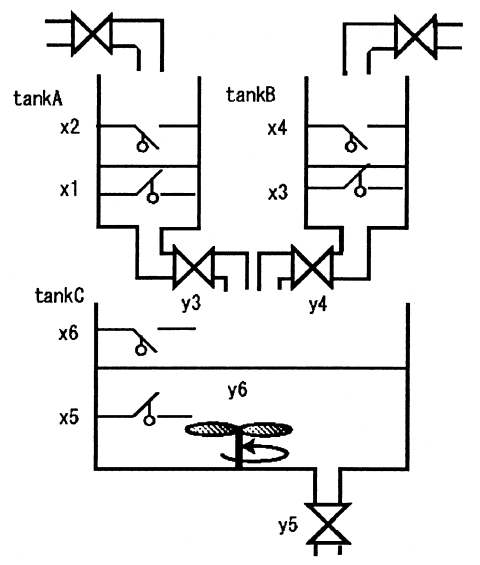

Fig. 2. An example of a tank system

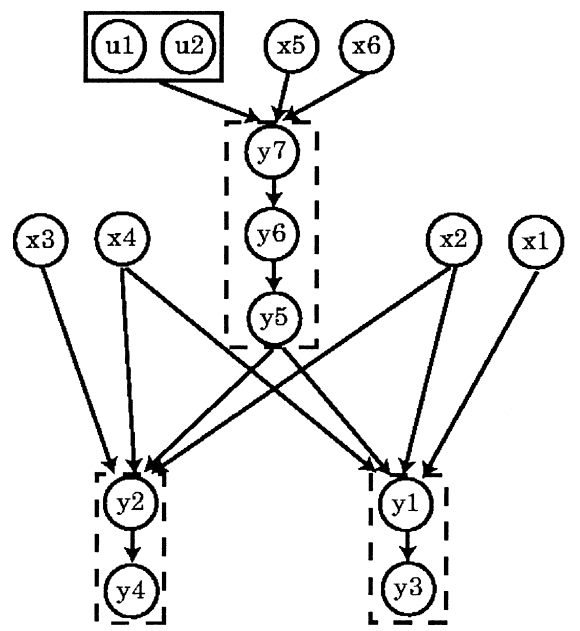

Fig. 3. Extracted layered structure using proposed method 


\title{
シーケンス制御プログラムの構造解析に基づく 機能モジュール抽出支援システムの研究
}

\author{
非会員 中村 聡* 正 員 藤本 康孝*
}

\section{A Method for Extraction of Function Modules of Sequential Control Programs Based on Structure Analysis}

Satoshi Nakamura*, Non-member, Yasutaka Fujimoto*, Member

\begin{abstract}
In this paper, a method to extract function modules from sequential control programs is proposed. A hierarchical structure of a given sequential program can be found by using association graph. If some or more variables are connected each other (strongly connected), the layered structure is not easy to find. Thus, based on the concept of Markov chain, the importance of variables can be conducted. We propose a new method to divide unclear layered variables in more details. An illustrative example of a tank control program is shown as an application of the proposed method.
\end{abstract}

キーワード：シーケンス制御，機能モジュール，階層構造，マルコフ連鎖，可到達行列

Keywords: sequential control, function module, hierarchical structure, Markov chain, reachability matrix

\section{1. はじめに}

シーケンス制御はフィードバック制御と共に重要な制御 方法で，産業界において広く用いられている。最近のシー ケンス制御に用いられている制御機器 PLC (Programmable Logic Controller）の処理能力の進歩は目覚しいものがある 一方で，ソフトウェアに関して新しい手法の研究・開発は 少ない。シーケンス制御で多く用いられているラダー図で は，リレー回路のように出力信号の生成条件を入力变数の 論理的なつながりで表現する。しかし, 可読性に問題があ るため, プログラムの制作に熟練・経験を要し，また，プ ログラムを設計した本人以外の技術者にとって理解が困難 であるために，保守性にも問題が生じている ${ }^{(6)}$ 。ラダー図 に用いられている各变数の構造的なつながりが分かりにく いことや，使用される変数の数が多数であることなどがそ の一因となっている。

この問題を解決する一つの方法は, 過去のプログラム資 源から有用な機能モジュールを抽出し活用することである。 これにより，システム開発コストの削減が期待できる。

本研究では，与えられたプログラムから各変数の関係を 抽出し, その変数間の階層構造を導出するアルゴリズムを提 案する。これにより, 過去のプログラムからの機能モジュー ルの抽出を支援できると期待できる。

\footnotetext{
*横浜国立大学大学院工学府

干 240-8501 横浜市保土ヶ谷区常盤台 79-5

Graduate School of Engineering, Yokohama National University

79-5, Tokiwadai, Hodogaya-ku, Yokohama 240-8501
}

\section{2. システムモデルの接続表現}

ラダー図における各変数の全体的な構造を解析するため に, 出力変数とその生成条件である入力变数との関係に着 目する。そのために，ラダー図から変数間の因果関係のみ に注目し，グラフを用いて因果関係を表現し，変数間の構 造的な情報を抽出することを考える。

例えば，ある変数 A が，単純にある変数 B になんらかの 影響を与えているとき, その接続関係たけに注目して, 困 1 のように情報の流れを有向グラフで表現することを考える。

いま, 接続行列 $T$ を $n$ 個の変数からなるラダー図モデル に対し以下のように定義する(1) (4)。

$$
t_{i j}=\left\{\begin{array}{l}
1 \cdots \text { 変数 } v_{j} \text { から変数 } v_{i} \text { へ接続されている } \\
0 \cdots \text { 変数 } v_{j} \text { から変数 } v_{i} \text { へ接続されていない }
\end{array}\right.
$$

ただし $, i, j$ は $1 \leq i, j \leq n$ を満たす整数とし,$t_{i j}$ は接続行 列 $T$ の $(i, j)$ 要素である。ラダー図に適用する場合, コイル (○) で表された出力变数とその生成条件となる接点 $(||)$ で 表された变数の因果関係のみに着目する。例えば, 図 2 の ようなラダー図の場合, 出力変数 $y_{1}$ に対して接点 $x_{1}, x_{2}$,

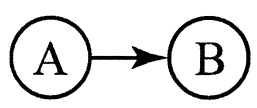

図 1 接続表現

Fig. 1. A description of connection. 


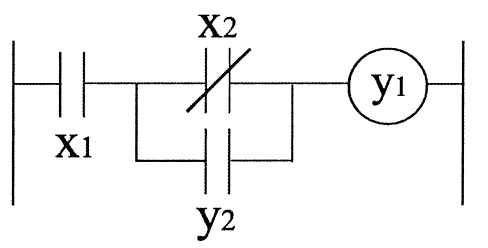

図 2 ラダー図の例

Fig. 2. An example of a ladder diagram.

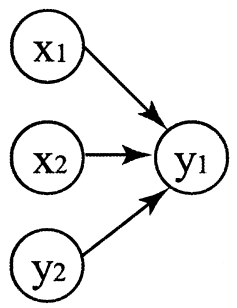

図 3 ラダー図の例の接続表現

Fig. 3. Connection graph of a ladder example.

$y_{2}$ が生成条件となっており, その因果関係のみに注目して 接続行列で表現すると, 図 3 の接続表現が得られる。すな わち，図 3 は $x_{1}, x_{2}, y_{2}$ が $y_{1}$ に影響することを表してい る。本表現では，生成条件となる接点が，コイルに直列的 (AND) に作用しているか並列的（OR）に作用しているか は問わず，その因果関係のみを抽出したものとなっている。 本モデルでは，変数の因果関係のみを簡略化してグラフ表 現することによって，その大域的な構造を求めることが特 長となっている。

影響を与える変数を列に，影響を受ける变数を行に表し， 接続表現を接続行列 $T$ で表すと,

$$
T=\left[\begin{array}{cccc}
y_{1} & y_{2} & x_{1} & x_{2} \\
0 & 1 & 1 & 1 \\
0 & 0 & 0 & 0 \\
0 & 0 & 0 & 0 \\
0 & 0 & 0 & 0
\end{array}\right] \begin{aligned}
& y_{1} \\
& y_{2} \\
& x_{1} \\
& x_{2}
\end{aligned}
$$

となる。な抏，行列の上部㧍よび右部の変数は，説明のた めに便宜的に記載するものである。

\section{3. 階層構造表現}

〈3・1 〉可到達行列による方法 ラダー図に扔ける各変 数の接続関係をグラフで表現することにより,様々な性質を 数学的な手法により導くことが可能となる。ラダー図の変 数をグラフの節点に対応させ，個々の節点を $\left\{v_{1}, v_{2}, \cdots, v_{k}\right\}$ とする。パス $\left(v_{1}, v_{2}\right)$ は, 節点 $v_{1}$ から節点 $v_{2}$ への長さ 1 の有 向路を表す。同様に, パス $\left(v_{1}, v_{2}\right),\left(v_{2}, v_{3}\right), \cdots,\left(v_{k-1}, v_{k}\right)$ は, $v_{1}$ から $v_{k}$ までのパスを表し, 表記されたパスの数がそのま ま変数間の有向路の長さを示す。 $v_{i}$ から $v_{j} へ$ へ有向路が存 在するということは， $v_{i}$ が $v_{j}$ へ到達可能であることに相当 する。

ここで, 節点 $v_{i}$ から $v_{j}$ への長さ $\ell$ の有向路の有無を求め ることを考える。接続行列 $T$ をブール代数上で $\ell$ 乗すると,

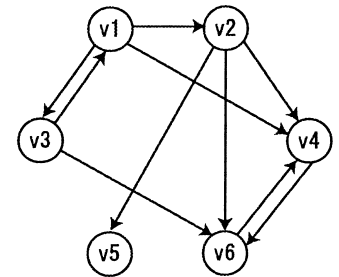

図 4 複雑な接続表現の例

Fig. 4. Complex connection relationship.

その $(i, j)$ 要素 $t_{i j}^{\ell}$ は, 節点 $v_{i}$ から $v_{j}$ への長さ $\ell$ の有向路の 有無を表すことになる。ラダー図に扔いては，変数 $v_{i}$ が変 数 $v_{j}$ にサイクルのステップを経て影響を及ぼすことを意 味する。節点の数 (変数の数) が $n$ 個のグラフに扔いては, 2 つの異なる節点間の有効路の長さは高々 $n-1$ であること を考慮すると，接続行列 $T$ に対して, $T^{0}, T^{1}, T^{2}, \cdots, T^{n-1}$ を計算し，ブール代数演算則に基づいて足し合わせること で，各節点から全ての節点への到達の可能性を表す行列を 得ることができる。これを可到達行列 $M$ と呼び, 次式で定 義する(4)。

$$
M=\sum_{k=0}^{n-1} T^{k}
$$

ただし， $T^{0}=I($ 単位行列 $)$ とする。

ここで, 図 4 の様な, ある変数の接続関係を表現したグ ラフを考える。この図から各变数の 2 次的， 3 次的，‥な つながりを把握することは困難である。そこで，まず可到 達行列を求め, 階層構造の抽出を試みる。

図より，接続行列は，

$$
T=\left[\begin{array}{ccccccc}
v_{1} & v_{2} & v_{3} & v_{4} & v_{5} & v_{6} \\
1 & 0 & 1 & 0 & 0 & 0 \\
1 & 0 & 0 & 0 & 0 & 0 \\
1 & 0 & 0 & 0 & 0 & 0 \\
1 & 1 & 0 & 0 & 0 & 1 & v_{1} \\
0 & 1 & 0 & 0 & 0 & 0 \\
0 & 1 & 1 & 1 & 0 & 0
\end{array}\right] \begin{gathered}
v_{2} \\
v_{4} \\
v_{5} \\
v_{6}
\end{gathered}
$$

と求まる。ただし，行列の上部抢よび右部の変数は，説明 のために便宜的に記載するものである。(3)より, 可到達行 列 $M$ は以下のようになる。

$$
M=\left[\begin{array}{llllll}
1 & 0 & 1 & 0 & 0 & 0 \\
1 & 1 & 1 & 0 & 0 & 0 \\
1 & 0 & 1 & 0 & 0 & 0 \\
1 & 1 & 1 & 1 & 0 & 1 \\
1 & 1 & 1 & 0 & 1 & 0 \\
1 & 1 & 1 & 1 & 0 & 1
\end{array}\right]
$$

この可到達行列 $M$ において, 各列の成分はその変数から 他の変数へ影響を与えるかどうかを示し，各行の成分はそ の変数が他の変数から影響を受けるかどうかを示す。可到 達行列 $M$ の $(i, j)$ 要素を $m_{i j}$ とすると, 第 $j$ 列の列和 $d_{j}$ は, 
表 1 可到達行列 $M$ とその行和および列和

Table 1. Reachability matrix $M$ and its row sum and column sum.

\begin{tabular}{c|cccccc|c}
\hline & $v_{1}$ & $v_{2}$ & $v_{3}$ & $v_{4}$ & $v_{5}$ & $v_{6}$ & $r_{i}$ \\
\hline$v_{1}$ & 1 & 0 & 1 & 0 & 0 & 0 & 2 \\
$v_{2}$ & 1 & 1 & 1 & 0 & 0 & 0 & 3 \\
$v_{3}$ & 1 & 0 & 1 & 0 & 0 & 0 & 2 \\
$v_{4}$ & 1 & 1 & 1 & 1 & 0 & 1 & 5 \\
$v_{5}$ & 1 & 1 & 1 & 0 & 1 & 0 & 4 \\
$v_{6}$ & 1 & 1 & 1 & 1 & 0 & 1 & 5 \\
\hline$d_{j}$ & 6 & 4 & 6 & 2 & 1 & 2 & \\
\hline
\end{tabular}

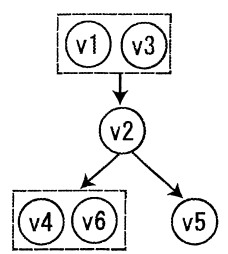

図 5 波及度による例題の階層構造

Fig. 5. Hierarchical structure of an example from donatable indices.

$$
d_{j}=\sum_{i=1}^{n} m_{i j}
$$

第 $i$ 行の行和 $r_{i}$ は,

$$
r_{i}=\sum_{j=1}^{n} m_{i j}
$$

と表され，表 1 のようになる。

$d_{j}$ は変数 $v_{j}$ が他の変数に与える影響の大きさを意味し, これをDonatable Index（波及度）と呼ぶ (4)。 $r_{i}$ は変数 $v_{i}$ が 他の変数から受ける影響の大きさを意味し, Receptive Index (受容度) と呼ぶ (4)。波及度の降順に変数を並び替えた可到 達行列 $M_{d}$ は次のようになる。

$$
M_{d}=\left[\begin{array}{llllll}
1 & 1 & 0 & 0 & 0 & 0 \\
1 & 1 & 0 & 0 & 0 & 0 \\
1 & 1 & 1 & 0 & 0 & 0 \\
1 & 1 & 1 & 1 & 1 & 0 \\
1 & 1 & 1 & 1 & 1 & 0 \\
1 & 1 & 1 & 0 & 0 & 1
\end{array}\right]
$$

このとき, 対応する変数は $\left(v_{1}, v_{3}, v_{2}, v_{4}, v_{6}, v_{5}\right)$ という順序 になっている。

列に全て 1 が並んでいる変数 $v_{1}, v_{3}$ は, 全ての変数に影 響を与えることから，このシステムの最上位であり，同じ 階層に属する。変数 $v_{2}$ は 2 番目の階層に属し, 変数 $v_{4}, v_{6}$ のグループと, 変数 $v_{5}$ のそれぞれに影響を与えていること が分かる。このように計算することによって階層構造が明 らかになる。(8) の関係を図的に表すと図 5 のようになる。

同様に，受容度に基づいて並び替えた場合でも，同じ結 果を得ることができる ${ }^{(1)}$ 。

〈3.2〉 既約システムの問題＼cjkstart実際のラダー図において

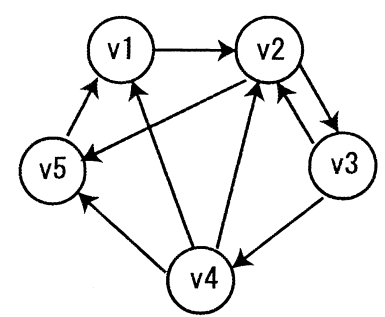

図 6 既約なシステム

Fig. 6. An example of an irreducible system

は，変数同士が互いに到達可能である場合が多い。このよ うな場合, 変数は互いに強連結であると定義される。前節 の方法によると, 全ての変数が互いに強連結であれば階層 構造は存在せず, 全ての変数が単一のグループに属するこ とになる。例えば，図6のシステムは全ての変数が互いに 到達可能であり, 可到達行列を求めると全要素が 1 となっ てしまい, 前節の方法では階層構造を抽出することができ ない。このような強連結な変数で構成されるシステムは, 既約なマルコフ連鎖システムと類似の概念により解析する ことができる。既約システムを解析するために, 影響度を 考慮した接続行列を導入する(2)(3)。これは, マルコフ連鎖に おける遷移確率行列に対応するものである。

変数 $v_{i}$ が変数 $v_{j}$ に与える影響の大きさを $p_{i j}$ で表す。 $0 \leq p_{i j} \leq 1$ とし, $p_{i j}$ を $(i, j)$ 要素とする行列 $P$ を正規化接 続行列と呼ぶ。

$$
P=\left[\begin{array}{cccc}
p_{11} & p_{12} & \cdots & p_{1 n} \\
p_{21} & p_{22} & \cdots & p_{2 n} \\
\vdots & \vdots & \ddots & \vdots \\
p_{n 1} & p_{n 2} & \cdots & p_{n n}
\end{array}\right]
$$

ただし, ある変数が他の変数に与える影響の総和を 1 とし, $j=1, \ldots, n$ について,

$$
\sum_{i=1}^{n} p_{i j}=1
$$

が成り立つものとする。すなわち, 正規化接続行列 $P$ の各 列和は 1 となる。

ここで，それぞれの変数が他の变数に等しく影響を及ぼ すと仮定し ${ }^{(3)}$, 正規化接続行列を次式で定義する。

〔定義 1〕正規化接続行列の $(i, j)$ 成分は, $i=1, \ldots, n$, $j=1, \ldots, n$ について,

$$
p_{i j}=\frac{t_{i j}}{\sum_{i=1}^{n} t_{i j}}
$$

とする。ここで, $\sum_{i=1}^{n} t_{i j}$ は接続行列の列和である。

よって図 6 に示すシステム例の接続行列 $T$ および, 正規 化接続行列 $P$ は

$$
T=\left[\begin{array}{lllll}
0 & 0 & 0 & 1 & 1 \\
1 & 0 & 1 & 1 & 0 \\
0 & 1 & 0 & 0 & 0 \\
0 & 0 & 1 & 0 & 0 \\
0 & 1 & 0 & 1 & 0
\end{array}\right]
$$




$$
P=\left[\begin{array}{ccccc}
0 & 0 & 0 & 1 / 3 & 1 \\
1 & 0 & 1 / 2 & 1 / 3 & 0 \\
0 & 1 / 2 & 0 & 0 & 0 \\
0 & 0 & 1 / 2 & 0 & 0 \\
0 & 1 / 2 & 0 & 1 / 3 & 0
\end{array}\right] \ldots \ldots \ldots \ldots \ldots
$$

となる。各変数の影響の大きさをべクトル表現したものを $\alpha$ とおくと，正規化接続行列と影響度 $\alpha$ の間には，次式が 成立する。

$$
\alpha=P \alpha
$$

上式より影響度 $\alpha$ は，正規化接続行列の固有值 1 に対応 する固有べクトルとなっていることが分かる。ベクトル $\alpha$ の各成分は，対応する変数の影響度を表し，その值の大小 は，他の変数から対応する変数への情報の流入の多寡を表 すと考えることができる。すなわち，ベクトル $\alpha$ から各変 数の順位付けが可能となり，同一の階層に属する変数間の 構造をより詳細に抽出することが可能となる。

図 6 のシステムの場合, (13)の正規化接続行列の固有值 1 に対する固有べクトルを求めると, $\alpha=[0.222,0.333,0.167$, $0.083,0.194]^{T}$ となり, その数值の小さいものから順番に対 応する変数を並べると $v_{4}, v_{3}, v_{5}, v_{1}, v_{2}$ となる。上位の 変数ほど他の変数に与える影響が大きく，下位の変数ほど 他の变数から影響を受けやすいと考えることができる。

〈3·3〉詳細な階層構造抽出法実際の制御システム においては，ラダープログラムに対する外部入力が存在し， 各変数に影響を与えていることが考えられる。そこで，入 力変数に関しても一定の割合で外部から影響が与えられる と仮定し，新しい既約な正規化接続行列を作成することを 試みる。

ここで，(9)を構成する部分行列を考え， $P_{11}$ を状態から 状態への正規化接続行列， $P_{12}$ を入力から状態への正規化 接続行列, $P_{21}$ を状態から入力への正規化接続行列, $P_{22}$ を 入力から入力への正規化接続行列とすると，新しい正規化 接続行列 $P^{\prime}$ を

$$
P^{\prime}=\left[\begin{array}{ll}
P_{11}^{\prime} & P_{12}^{\prime} \\
P_{21}^{\prime} & P_{22}^{\prime}
\end{array}\right]=\lambda\left[\begin{array}{ll}
P_{11} & P_{12} \\
P_{21} & P_{22}
\end{array}\right]+(1-\lambda)\left[\begin{array}{l}
0 \\
Q
\end{array}\right]
$$

と定義する。ただし，

$$
Q=\left[\begin{array}{ccc}
\frac{1}{m} & \cdots & \frac{1}{m} \\
\vdots & \ddots & \vdots \\
\frac{1}{m} & \cdots & \frac{1}{m}
\end{array}\right] \ldots \ldots \ldots \ldots \ldots \ldots \ldots \ldots \ldots \ldots \ldots
$$

であり，また，重み係数入は対象モデルに応じて調整する $0 \leq \lambda \leq 1$ の正数である。また， $m$ は入力变数の数である。 $Q$ は全ての要素が $1 / m$ である $m$ 行 $n$ 列の行列である。こ こで, $n$ は全変数の数である。(15) の変形により既約なシ ステムが生成される。

\section{4. モデル例}

モデル例として，図 7, 図 8 のシーケンス制御システム の例を考える。以下では, 簡単化のため, 必要最小限の記 述のみを扱う。

このタンクシステムは, タンク $\mathrm{A}, \mathrm{B}, \mathrm{C}$ の三つのタン クから構成され, 各夕ンクにはそれぞれ溶液を注入するバ ルブ $\left(y_{1}, y_{2}\right)$ がセットされている。ただし，タンク Cへ の溶液の注入はタンク $\mathrm{A}, \mathrm{B}$ からバルブ $\left(y_{3}, y_{4}\right)$ を通し て行われるとし，タンク Cには，放流バルブ $\left(y_{5}\right)$ と撹汼 するためのミキサ $\left(y_{6}\right)$ が取り付けられている。

タンク A， B には，注入バルブ $\left(y_{1}, y_{2}\right)$ を通して, 一定 量 $\left(x_{2}, x_{4}\right)$ に達するまで溶液が注入される。一定量に達 すると注入を停止し，バルブ $\left(y_{3}, y_{4}\right)$ を通して A, B 同時 にタンク Cへ溶液を注入する。それぞれのタンクの残量が 一定量 $\left(x_{1}, x_{3}\right)$ 以下になれば，バルブ $\left(y_{3}, y_{4}\right)$ を閉め,

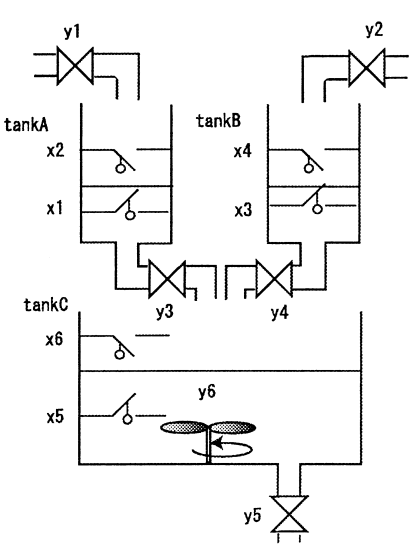

図 7 タンクシステム

Fig. 7. An example of a tank system.

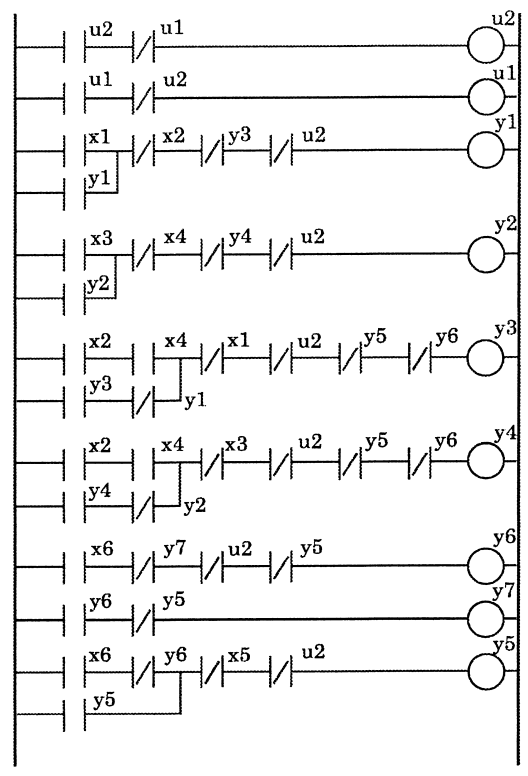

図 8 タンクシステムのラダー図

Fig. 8. A ladder diagram for a tank system. 
表 2 タンクシステムの変数表

Table 2. Variables of a tank system.

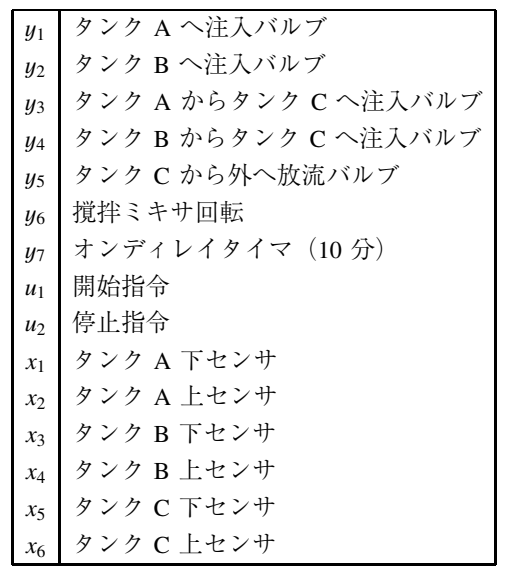

注入を停止する。一方でタンク C は，タンク $\mathrm{A}, \mathrm{B}$ からの 注入によって, 溶液が一定量 $\left(x_{6}\right)$ に達すれば摚拌ミキサ $\left(y_{6}\right)$ を一定時間回転させる。一定時間, タンク Cのミキサ を回転させたのち，タンク C に取り付けられている放流バ ルブ $\left(y_{5}\right)$ を開き, 液面が下限 $\left(x_{5}\right)$ に達するまで外部へ 溶液を流出させる。図 8 のラダー図は, 以上の一連の動作 をするようにプログラムされている。なお，プログラムに 用いている変数を表 2 に示す。スタートスイッチ $\left(u_{1}, u_{2}\right)$ に関しては，オルタネート動作をするスイッチを想定して おり，同時に ONになることや，OFFになることはないも のとする。

生成条件となる接点がコイルに直列的（AND）に作用し ているか並列的（OR）に作用しているかは問わず，その 因果関係のみを抽出し接続行列を求めると，(17)のように なる。

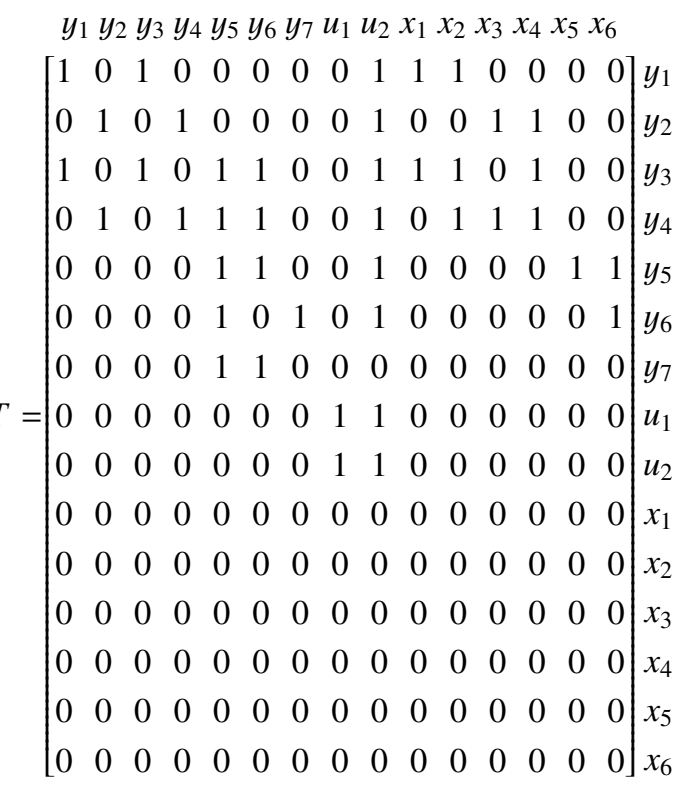

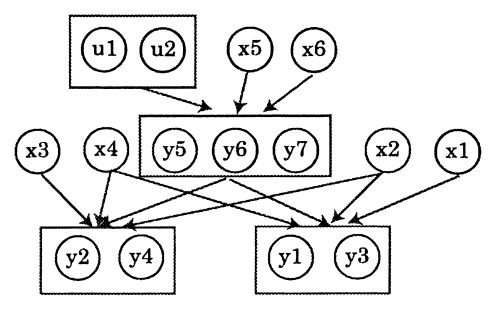

図 9 受容度・波及度により抽出された階層構造

Fig. 9. Extracted layerd structure using donatable indices and receptive indices.

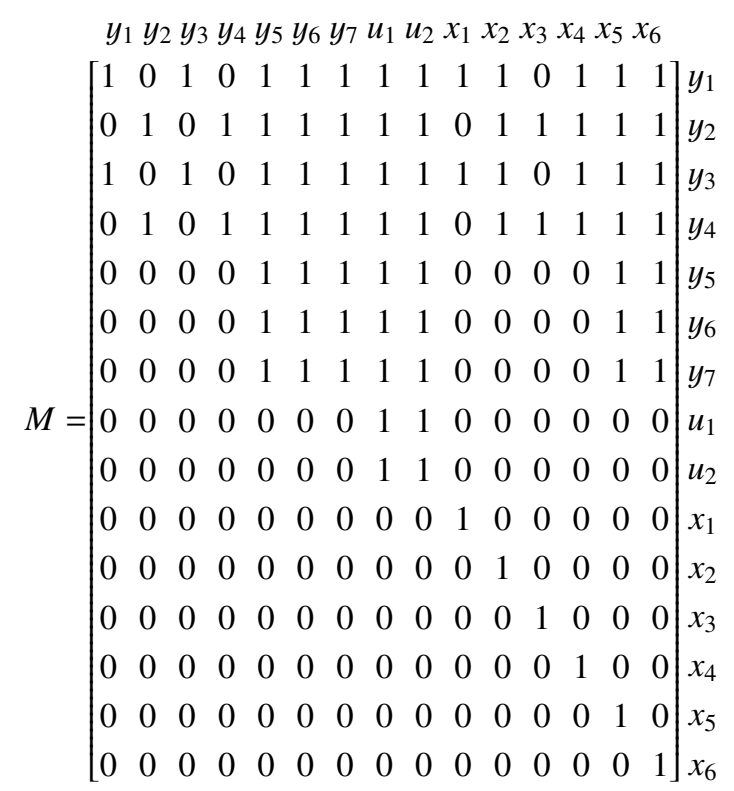

(17) の接続行列から可到達行列 $M$ を求めると (18) が得 られる。受容度・波及度を用いた〈3・1〉節の手法により階 層構造を抽出すると，図9のようになる。それぞれ，入力 変数や, センサに対応する変数が上位となり, 関連する出 力変数のグループに影響を与えていることが抽出されてい る。ただし, 変数 $u_{1}, u_{2}$ のグループ, $y_{5}, y_{6}, y_{7}$ のグルー プ, $y_{2}, y_{4}$ のグループ, $y_{1}, y_{3}$ のグループがそれぞれ強連 結となり, これらグループ内では詳細な階層構造は抽出さ れなかった。ラダー図からも自明なように，これらの変数 は強連結で打互いに影響を及ぼしあうために同じ階層とし て表現されてしまう。しかし, 同一階層に属する变数でも ラダー図で使用されている頻度は異なっているため，同一 階層内に㧈いてもより詳細な階層構造が存在すると考えら れる。

次に, 互いに強連結な同一階層内の变数間の詳細な階層構 造を抽出するため, まず, $33 \cdot 2>$ 節の手法を適用する。この夕 ンクシステムの場合, 部分的に強連結な構造を有しているが, システム全体は強連結ではない。正規化接続行列 $P$ は重複 する固有值 1 を持っており, 対応する固有べクトルは 2 本存 在し, $\alpha=[0,1,0,1,0,0,0,0,0,0,0,0,0,0,0]^{T},[1,0,1,0,0$, $0,0,0,0,0,0,0,0,0,0]^{T}$ となっている。すなわち, 影響度 $\alpha$ には 2 つの解が存在し, 図 9 の最下層の $\left(y_{2}, y_{4}\right)$ のグルー 
表 3 タンクシステムの固有ベクトルの值

Table 3. An eigenvector of a ladder diagram for a tank system.

\begin{tabular}{|c|l|}
\hline$y_{1}$ & 0.192826 \\
$y_{2}$ & 0.192826 \\
$y_{3}$ & 0.2077 \\
$y_{4}$ & 0.2077 \\
$y_{5}$ & 0.0312132 \\
$y_{6}$ & 0.0244692 \\
$y_{7}$ & 0.011124 \\
$u_{1}$ & 0.0285714 \\
$u_{2}$ & 0.0285714 \\
$x_{1}, \cdots, x_{6}$ & 0.0125 \\
\hline
\end{tabular}

プに集約される解と, 最下層の $\left(y_{1}, y_{3}\right)$ のグループに集約さ れる解が得られ, 望むような階層構造は抽出できていない。 この場合のように既約でないシステムにく3・2〉節の手法を 適用しても，有効な構造は抽出できないことが分かる。

そこで, 入力変数 $\left(u_{1}, u_{2}, x_{1}, \ldots, x_{6}\right)$ を考慮した $\langle 3 \cdot 3\rangle$ 節 の手法を適用する。このとき，タンクシステムの正規化接 続行列 $P^{\prime}$ は,

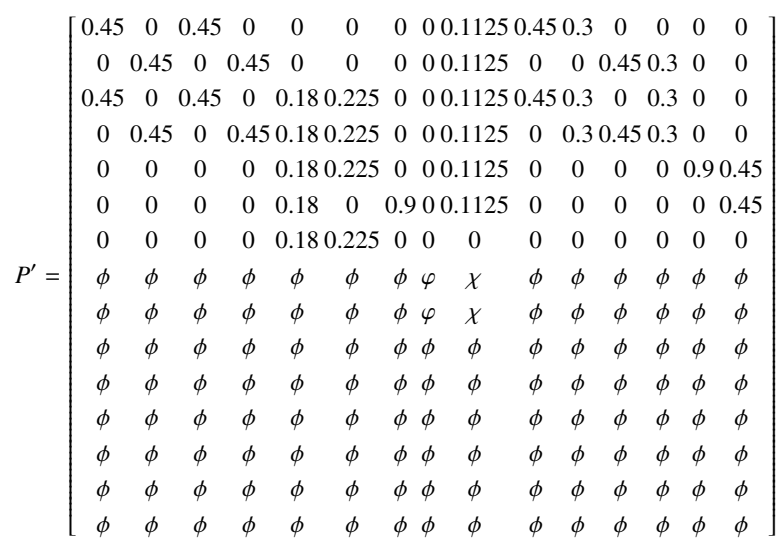

となる。ただし $, \phi=0.0125, \varphi=0.4625, \chi=0.125$ であ る。また， $\lambda=0.9$ として計算を行った。重み係数 $\lambda$ は，元 の正規化接続行列を大きく変化させることなく，入力変数 の影響を付加する役割を担うことから，1に近い值に設定 することが望ましく，経験的に 0.9 程度に決定している。

この正規化接続行列から固有值 1 に対応する固有べクト ルを求めた。得られた変数順位（固有ベクトルの成分）を 表 3 に示す。

この結果に基づいて階層構造を求めると, 図 10 のように なる。図 9 と比較すると, 同一階層に属していた変数がさ らに順位付けされていることが分かる。例えば，タイマー 変数 $y_{7} \rightarrow$ 撹汼ミキ开回転 $y_{6} \rightarrow$ 放流バルブ $y_{5}$ という関係が 抽出されている。

\section{5. 機能モジュール抽出支援}

本章では，4 章のタンクシステムの例を用いて，提案す る手法により階層構造を抽出したのちに，これをラダー図 に活用する方法について述べる。

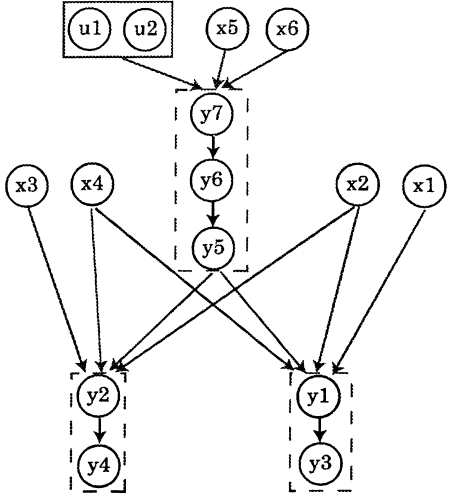

図 10 提案手法による階層構造抽出

Fig. 10. Extracted layerd structure using proposal method.

階層構造が抽出されると, 变数がお互いにどの様に影響を 及ぼ合っているか視覚的に理解可能となる。そこから関 係の近い変数群をファンクションブロックとして抽出し，そ の変数群に影響を及ぼす変数をそのファンクションブロッ クの入力, その変数群の中で他の変数に影響を与える変数 をそのファンクションブロックの出力とすることで，カプ セル化された機能モジュールがファンクションブロックと して抽出できる。

タンクシステムの例では, 図 10 の階層構造から, 例え ば，お互いに関係の近い $y_{7}, y_{6}, y_{5}$ を一つのブロックとし て考えると, 入力が $u_{1}, u_{2}, x_{5}, x_{6}$, 出力が $y_{5}, y_{6}$ という ファンクションブロックとなり，撹拌ミキサを起動し，一 定時間回転させたのち停止し, 溶液を放流する, という一 連の制御を担う機能モジュールを抽出することができる。 同様にして，一つのプログラムから複数の機能モジュール を抽出できる。

ところで，実システムにおけるラダー図では，相互イン ターロックが多用されることが多く，相互インターロック に関わる変数は強連結になるので, 同一階層に属する变数の 数が多くなることが想定される。このような場合, $\langle 3 \cdot 1\rangle$ 節 の手法では，同一階層内で機能を分割することができず， その適用範囲は限定的となる。〈3·3 節の手法を用いるこ とで，この問題を部分的に解決することができる。例えば， 図 10 より $y_{7}, y_{6}, y_{5}$ からなるブロックを更に分割し， $y_{6}$, $y_{5}$ を一の機能ブロックとして抽出することが可能である。 本モデル例よりもシステム規模が大きい場合にその有効性 が発揮されると考えられる。

なお，現時点では，どの変数群を一つのブロックと捉え るかは人間の判断によるため, 本手法は機能モジュールを 抽出するための支援システムという位置付けとなっている。

\section{6. まとめ}

ラダー図の変数間の関係をグラフにおける接続関係とみ なし，受容度，波及度を用い，かつ，マルコフ連鎖に類似 した正規化接続行列を導入することによって，变数の影響 
度を求め, 変数の受容度, および, 機能モジュールの抽出 を支援する手法を提案した。タンクシステムをモデル例と して, 各変数間の階層構造を詳細に抽出できることを示し た。これにより，過去のラダープログラムから，有効な機 能モジュールを抽出する際に有益な情報を提示することが できる。

今後の課題として, より複雑な, 相互インターロックを 多用した強連結の多いラダー図の場合でも，同様の結果が 得られることを確認することが挙げられる。

(平成 18 年 10 月 12 日受付，平成 19 年 3 月 23 日再受付)

\section{文献}

(1) S. Nakamura and Y. Fujimoto: "Structure Analysis of Logic Controll Programs", IECON'04, FC-7-26 (2004)

(2) Y. Uchimura, T. Yakoh, and K. Onishi: "A Controller Design Method on Decentralized Systems”, IECON'04, SA-6-6 (2004)

(3) S. Brin and L. Page: "The Anatomy of a Large-Scale Hypertextual Web Search Engine", WWW7/Computer Networks, Vol.30, pp.1-7: 107-117 (1998)

(4) T. Seki, Y. Fujimoto, T. Yakoh, and K. Onishi: "An Expression of Dynamical System Connection in Decentralized Autonomous Control", Trans. IEE of Japan, Vol.120-D, No.1, pp.80-87 (2000-1) (in Japanese) 石健 信・藤本康孝・矢向高弘・大西公平：「自立分散制御における システムのダイナミカル結合の一表現法」, 電学論 D, 120,1, pp.80-87 (2000-1)

(5) S. Nakamura and Y. Fujimoto: "A Basic Analysis of Structure of Sequential Control Programs for Extraction of Function Modules", Proc. of IEEJ Electronics, Infomation and Systems Conference, GS16-4, p.77 (2003) (in Japanese)
中村 聡・藤本康孝：「機能モジュール抽出のためのシーケンスプ ログラムの構造解析に関する基礎研究」, 電学電子・情報・システム 部大, GS16-4, p.77 (2003)

（6）関口 隆·高橋 浩・青木正夫・下川勝千・薦田憲久：「シーケンス 制御工学 新しい理論と設計法」,電気学会 (1988)

（7）森村英典・高橋幸雄：「マルコフ解析」, 日科技連 (1979)

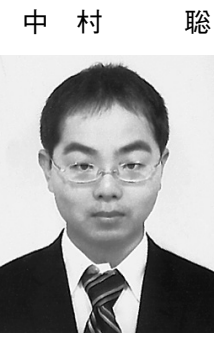

（非会員） 2003 年 3 月横浜国立大学工学部電子 情報工学科卒業。2005 年 3 月横浜国立大学大学 院工学府物理情報工学専攻博士課程前期修了。同 年 4 月より日立製作所勤務, 現在に至る。主とし て, シーケンス制御に関する研究に従事。

藤 本 康 孝 （正員） 1998 年 3 月横浜国立大学大学院工学研

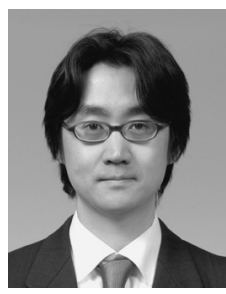
究科電子情報工学専攻博士課程修了。同年 4 月慶 応義塾大学理工学部嘱託助手。1 999 年 4 月より 横浜国立大学工学部電子情報工学科助手, 2000 年 4 月同講師, 2001 年 4 月工学研究院知的構造の 創生部門助教授，現在に至る。博士 (工学)。主 として生産システム, シーケンス制御，モーショ ンコントロール，ロボティクスに関する研究に従 事。IEEE，日本ロボット学会等の会員。 